\title{
Articles
}

\section{Measuring Success of the Czech Financial Administration before the Supreme Administrative Court: Partial Results of a Quantitative Research of Court Proceedings}

\author{
Marie Karfíková, ${ }^{*}$ Jakub Vojtěch ${ }^{* *}$
}

\begin{abstract}
* Prof. JUDr. Marie Karfíková, CSc., Head of the Department of Financial Law and Financial Science at the Faculty of Law, Charles University, the Czech Republic, attorney-at-law, President of the Arbitration Court attached to the Czech Chamber of Commerce and the Agricultural Chamber of the Czech Republic and a member of the Centre of Information and Organization of Public Finances and Tax Law Research in Central and Eastern Europe. This paper has been elaborated within the programme "PROGRES Q02 - Publicization of Law in the European and International Context" which is realized in 2019 at the Faculty of Law of the Charles University. ORCID: 0000-0002-5655-7858. (e-mail: karfikov@prf.cuni.cz)

** JUDr. Jakub Vojtěch, a PhD candidate at the Faculty of Law, Charles University, Czech Republic. This text has been elaborated within the project of the student scientific research "Finance and information technology as drivers of legal regulation in the European Union countries and their criminal law aspects" which is realized in the years 2017-2019 at the Faculty of Law of the Charles University, SVV 260 360/2017. ORCID: 0000-0003-0636-8079. (e-mail: vojtechj@prf.cuni.cz)
\end{abstract}

\begin{abstract}
The paper discusses the issues of the actions and measures of tax authorities challenged by taxpayers before the administrative justice and thus serves as a contribution to the discussion on efficiency of tax authorities and public administration in general. The authors first address the currently discussed problems of the Czech tax law and tax administration. This is followed by describing their quantitative research focused on answering the question of what is actually the success rate of the Czech Financial Administration before the Supreme Administrative Court in the proceedings on cassation complaints. The ratio of cassation complaints for or against the Financial Administration can be an interesting indicator showing the performance of public administration. Afterwards, it follows an explanation of methodology and presentation of results of the first part of the quantitative research that is focused on analysing the Supreme Administrative Court's rulings on cassation complaints brought (both by taxpayers or the Financial Administration) against the Regional Courts' rulings on legal actions against unlawful interference by the Financial Administration with the taxpayers' rights that cover the period 2013-2017.
\end{abstract}

Keywords: The Czech Republic; financial administration; court proceedings; analysis 


\section{Introduction}

In the Czech Republic, in principle any administrative decision, interference or failure to act of an administrative authority can be challenged before the administrative justice by way of a legal action brought by a natural or legal person. The actions and measures of tax authorities (in Czech: spravce dane) are no exception as tax authorities are only considered specialised administrative authorities. While only a taxpayer can sue the tax authority before an administrative court (in the Czech Republic before a Regional Court, in Czech: krajsky soud), extraordinary remedy in the form of a cassation complaint (appeal in cassation, in Czech: kasacni stiznost) against a Regional Court's ruling can be brought before the Supreme Administrative Court (hereinafter: "SAC", in Czech: Nejvyssi spravni soud) by both of them.

Based on the currently discussed problems of Czech tax law and tax administration, the authors have decided to conduct a quantitative research with the main purpose to determine the ratio of cassation complaints for or against the tax authorities in the past five years (from January 1, 2013 to December 31, 2017), i.e. since the establishment of the new structure of the Financial Administration of the Czech Republic as of January 1, 2013. The main part of the quantitative research is yet to be realised, results of the first part are already finished. The primary focus of the paper thus consists in the presentation of the results of the first part that includes examination of rulings on cassation complaints brought either by the taxpayer or the tax authority against the Regional Courts' rulings in cases of unlawful interference with the taxpayers' rights in the period 2013-2017.

\section{Economic Prosperity of the Czech Republic and Problems Related to Tax Law and Tax Administration}

The Czech Republic is experiencing an economic upswing: dynamic economic growth makes the country one of the fastest growing countries in the whole European Union, ${ }^{1}$ European record low unemployment rate, ${ }^{2}$ rising wages, ${ }^{3}$ strong exports, ${ }^{4}$ manageable inflation ${ }^{5}$ and strong financial sector. ${ }^{6}$ This is the big economic picture of the Czech Republic in 2018 and in the years before. According to private sector economic analysts, ${ }^{7}$ international consulting firms $s^{8}$ and public sector institutions (e.g. the European Commission, ${ }^{9}$ OECD, ${ }^{10}$ the Czech Ministry of Finance ${ }^{11}$ and the Czech National Bank ${ }^{12}$ ), the economic performance of the Czech Republic should also be above average in the upcoming months and years. Even the entrepreneurs themselves are optimistic. ${ }^{13}$

Yet, in the long term, less optimistic data and information not influenced by the current conjunction can be found. They are more of a structural nature combined with certain economic and legal deficiencies which can be observed over a longer period of time. The area of taxation and tax law can serve as a good example.

Lack of stability and predictability of future tax law developments and never-ending partial amendments of (not only) tax laws are broadly considered (according to the private sector ${ }^{14}$ and even public officials ${ }^{15}$ ) one of the biggest problems of the Czech legislation. ${ }^{16}$ Another problem consists in introducing completely new tax obligations, very slow pace of 
bureaucracy reduction and relatively slow implementation of electronic contact with the tax authorities (the Financial Administration of the Czech Republic). Last but not least, a strong criticism has been recently directed against the approach of the tax authorities when enforcing obligations from taxpayers, especially in the field of the value added tax (hereinafter: "VAT"). For instance tax controls are becoming more detailed and with increasing demands. ${ }^{17}$

In general, the tax authorities have recently adopted increasingly restrictive measures to collect as much tax as possible. One of the new measures in the field of tax collection is the extended application of "securing orders" (in Czech: zajistovaci prikazy) and their subsequent enforcement within a very short time especially in VAT-related matters. ${ }^{18}$ They may be used before the actual tax liability is determined or before a tax control is completed, largely depending on the tax authority's discretion. Securing orders increasingly often serve to collect funds on the tax authority's account where the future collection of the estimated tax liability appears to be endangered while the deadline for depositing the funds does not exceed three workdays. Tax authorities may also freeze bank accounts and attach other assets. These actions, usually undertaken very quickly, may have the effect of paralysing, or even terminating a corporation's business activities. It is to be pointed out that the number of cases in which the tax authorities decided to enforce taxpayers' assets based on securing orders has increased dramatically over the last years. ${ }^{19}$ This issue was even the subject of debates in the Chamber of Deputies. ${ }^{20}$

In recent years, there can also be noticed a growing number of court rulings stating that securing orders and other instruments performed by the tax authorities were issued or enforced unlawfully. Especially the decision-making practice of the SAC is correcting to some degree the approach of the tax authorities. ${ }^{21}$ The Czech media have reported a number of cases in which the tax authorities intervened against taxpayers who later found support from the administrative courts. ${ }^{22}$ In addition, the tax authorities do not always take these court rulings into account, ${ }^{23}$ albeit officially declaring that they proceed with prudence and that their enforcement is professionally supervised. ${ }^{24}$ The Financial Administration of the Czech Republic is also often trying to point to the cases, in which it was successful ${ }^{25}$ or state that it actually respects the case law of administrative courts. ${ }^{26}$

The issue of court cases for or against the tax authorities is what our quantitative analysis is dealing with. To be more precise, it consists in answering the question of what is actually the success rate of the Financial Administration of the Czech Republic before the SAC. The main focus thus lies in determining its success if its actions and measures are questioned by taxpayers before the administrative justice.

\section{Financial Administration and Administrative Justice in the Czech Republic}

As of January 1, 2013, the structure of tax authorities considerably changed ${ }^{27}$ with the establishment of the Financial Administration of the Czech Republic (in Czech: Financi sprava Ceske republiky, hereinafter: "Financial Administration") as the main tax authority and the General Financial Directorate (in Czech: Generalni financni reditelstvi) as its 
central body. The head of the General Financial Directorate is the Director General, who is appointed and removed by the Government of the Czech Republic based on proposal by the Minister of Finance. Its subordinate body is the Appellate Financial Directorate (in the position of the appellate body) to which sixteen Financial Offices are further subordinated (the responsibility of which is territorially limited to one of the sixteen Regions of the Czech Republic) and the Specialized Financial Office (administrating certain taxes of special taxpayers like banks and insurance companies). ${ }^{28}$

The Czech system of administrative justice consists of two components: Regional Courts, seated in each of the Czech sixteen regions, and the SAC with its seat in Brno. The SAC being the supreme judicial body specialised exclusively in the field of administrative justice has a special additional task in ensuring the unity and legality of the case law of Regional Courts and administrative authorities. The principal instrument for achieving this objective is the cassation complaint. The SAC is entitled to hear cassation complaints challenging final rulings of Regional Courts in matters of administrative justice, in which complainants seek the 1 . annulment of an administrative decision by way of legal action against a decision of an administrative authority; 2 . protection against a failure to act (inaction by an administrative authority); 3. protection against an unlawful interference by an administrative authority with individuals' public right and 4. protection in other matters (like electoral matters and local and regional referendum, matters concerning political parties or political movements, judicial review of measures of a general nature, competence complaints). ${ }^{29}$

The Czech system of administrative justice can be marked as a one-instance-system of judicial review, i.e. Regional Courts acting as courts of first and last instance with no appeal or other ordinary judicial remedy being permissible. There is, however, the possibility of filing and extraordinary remedy - the cassation complaint - before the SAC. It should be noted that, albeit designed as an extraordinary remedy, i.e. a remedy against the final ruling of Regional Courts, the admissibility criteria for a cassation complaint before the SAC are defined quite broadly. A cassation complaint has to be filed within two weeks of the Regional Court's decision becoming final and lie against any final decision of a Regional Court in administrative matters, provided it is not expressly precluded by law. Both errors in the assessment of substantive legal provisions, as well as errors in the procedure before the Regional Court might be challenged. A complainant before the SAC must be represented by an attorney. As a rule, the SAC decides on a cassation complaint without an oral hearing, albeit a hearing might be ordered if further evidence is deemed necessary. ${ }^{30}$

While only a taxpayer can sue the Financial Administration before the Regional Court, a cassation complaint against a Regional Court's ruling can be brought by both of them. By the nature of the administrative court proceedings, the Financial Administration can be sued only within three cases, namely: 1 . decision of the tax authority (the Financial Administration, i.e. one of its bodies - Financial Offices); 2. failure of the tax authority to act and 3. unlawful interference by the tax authority with the taxpayers' rights. 


\section{The Aim of the Quantitative Research of Court Proceedings}

Based on the new structure of the Financial Administration, we have decided to pay attention to the past five years (i.e. the period from January 1, 2013 to December 31, 2017) and to examine what is the success rate of the Financial Administration before the administrative justice, or more precisely its success rate in the proceedings on cassation complaints before the SAC. It is clear, that despite the fact that the SAC has the competence to decide on cassation complaints against the rulings of Regional Courts in all of the three matters 1-3, in reality, not every decision of the Regional Court has to be (or can be) challenged by a cassation complaint. Despite that we believe that in view of the broad admissibility criteria for a cassation complaint, the results of a quantitative research will reflect most of the relevant cases.

The data obtained from the quantitative research might be an interesting indicator showing the performance of the Financial Administration in cases heard by the administrative justice. After a deeper analysis, the data might reflect annual developments in the success rate since the establishment of the Financial Administration in 2013, while possible developments could be linked to the number of employees of the Financial Administration (according to the numbers announced in its annual reports) or other factors. Most importantly, the data could serve for a better understanding of public administration and its development and might be an inspiration for legal scholars and practitioners in other jurisdictions considering to undertake a similar approach towards a better understanding of public administration. However, it is obvious that a complete comparability of the results achieved cannot be possible, in particular due to the different judicial systems and models of public administration. It is also clear that that the data will not capture the individual nature of any case. Nevertheless, we are convinced that the ratio of cassation complaints for and against the Financial Administration can be an interesting indicator showing the court performance of one part of the Czech public administration.

Measuring the success rate of the Financial Administration in proceedings on cassation complaints before the SAC in the past five years (i.e. in the period 2013-2017) consists, according to our calculations, in an analysis of several thousand rulings covering the three fields, i.e. the cases in which Regional Courts decided on 1. a legal action against a decision of the Financial Administration (Financial Office); 2. a legal action for the failure of the Financial Office to act and 3. a legal action against unlawful interference by the Financial Office with the taxpayers' rights. Given this amount of rulings, we have decided to proceed step by step and have first analysed the SAC's rulings concerning the third area, i.e. the SAC's rulings on cassation complaints brought either by the taxpayer or Financial Office against a Regional Court's decision in the cases of unlawful interference by the Financial Office issued in the period 2013-2017. In the following chapter we first explain the methodology of the first part of the research which is subsequently followed by the description and explanation of the results achieved. 


\section{The Methodology and Scope of the First Part of the Research}

As the first part of the quantitative research, we have decided to proceed with the SAC's rulings on cassation complaints brought both by the taxpayer and the Financial Administration (Financial Office) in matters of unlawful interference in the period 20132017, namely those in which Regional Courts decided on a legal action brought by taxpayers against unlawful interference by the Financial Office. As mentioned earlier, this limited number of rulings is part of a much broader quantitative research since it is also intended to analyse the SAC's rulings in two other main fields, namely rulings on cassation complaints against decisions of Regional Courts on 1. legal actions against a decision of the Financial Office and 2. legal actions for the failure of the Financial Office to act.

As for legal actions against unlawful interference, the concept of interference with individual rights refers to a broad scale of activities of administrative authorities, e.g. an unlawful tax control conducted by the Financial Office etc. Protection against unlawful interference is a complementary form of legal protection, it can only be invoked against some type of activity of an administrative authority which does not result in the issuance of a formal decision that could be challenged (by way of legal action against a decision of an administrative authority). Logically speaking, an unlawful interference is also distinct from the failure to act. In a certain sense then, the protection against unlawful interference creates a "left-over" category, in which a person can challenge the activities of an administrative authority which encroaches upon individual public rights, but which does not constitute a decision or failure to act. ${ }^{31}$

There is a strict time limit for filing such an action, namely within two months of the day the legal or natural person became aware of the interference (the "subjective" time limit) or, at the latest, within two years of the day the interference took place (the "objective" time limit). Should the action be successful, the court will order the administrative authority to discontinue violating the legal or natural person's rights or will confirm the unlawfulness of the interference. It will further order the restoration of the status quo which prevailed prior to the interference. ${ }^{32}$

We have used the following methodology to perform the first part of the quantitative research on the SAC's rulings related to the Financial Administration's unlawful interference:

a) all the rulings of the SAC have been taken from the website database of the SAC; ${ }^{33}$

b) in the website database, only rulings concerning the matter of "Taxes" (in Czech: dane) have been selected;

c) only rulings on cassation complaints issued between January 1, 2013 to December 31, 2017 have been taken into account;

d) cassation complaints brought both by the taxpayer (natural or legal person) and the Financial Office against decisions of Regional Courts on legal actions against unlawful interference by the Financial Office with the taxpayers' rights have been considered;

e) only rulings containing the words "Financial Office" (in Czech: danovy urad) have been selected in the website database of the SAC, i.e. rulings in which the Financial Office was the party complained in the proceedings before the Regional Court; 
f) for the purpose of avoiding rulings of procedural character (i.e. not on the merits of the case), only rulings in the form of a judgment (in Czech: rozsudek) have been taken into account;

g) any subsequent intervention by the Constitutional Court and possible annulment of the SAC's judgment have not been considered;

h) partly justified (successful) cassation complaints have been considered as overall successful unless the applicant had success only as to costs;

i) in the event that a cassation complaint was brought both by the defendant (Financial Office) and the plaintiff (taxpayer), we consider which cassation complaint was successful according to the judgement.

\section{Results of the First Part of the Quantitative Research: Cassation Complaints on Unlawful Interference in Tax Matters}

Based on the above criteria, we are able to present the results of the first part of the research concerning the rate of success of the Financial Administration before the SAC. The results concern only the cassation complaints (filed both by the taxpayer and the Financial Office) seeking to set aside a Regional Court's ruling on protection against an unlawful interference by a Financial Office with the taxpayers' rights. As for a more detailed analysis of the judgments on cassation complaints related to unlawful interference in tax matters in the period 2013-2017, please see below Tables 1-5 which summarise the results of our research.

The total number of judgments in the past five years (from January 1, 2013 to December 31,2017 ) on cassation complaints filed in cases of unlawful interference in tax matters is reflected in Table 1 . They result in some 109 SAC judgements based on the criteria set in the previous chapter.

Table 1.

The total number of "Unlawful Interference" tax cases before the SAC in 2013-2017

\begin{tabular}{|c|c|c|c|c|c|c|}
\hline Year & 2013 & 2014 & 2015 & 2016 & 2017 & $2013-2017$ in total \\
\hline Total No. of Cases & 7 & 23 & 22 & 26 & 31 & 109 \\
\hline
\end{tabular}

Source: Compiled by the authors.

Table 2 divides the total number of judgments in the past five years (from January 1, 2013 to December 31,2017 ) on cassation complaints filed in cases of unlawful interference in tax matters based on the criteria of the applicant, i.e. whether filed by 1. the Financial Administration (its Financial Offices) or 2. the taxpayer that himself also challenged the unlawful interference by the Financial Office before the Regional Court. Based on the criteria set in the previous chapter, out of the 109 SAC judgements, only 6 were issued following the cassation complaints filed by the Financial Offices, meanwhile 103 judgments were issued following the cassation complaints filed by the taxpayer. 
Table 2.

Appellants in 2013-2017

\begin{tabular}{|l|c|c|r|r|r|r|}
\hline \multicolumn{1}{|c|}{ Year } & 2013 & 2014 & 2015 & 2016 & 2017 & 2013-2017 in total \\
\hline Financial Office & 0 & 2 & 2 & 0 & 2 & 6 \\
\hline Taxpayers & 7 & 21 & 20 & 26 & 29 & 103 \\
\hline Both & 7 & 23 & 22 & 26 & 31 & 109 \\
\hline
\end{tabular}

Source: Compiled by the authors.

Table 3 summarises the cases of failure and success of both 1. the Financial Administration (its Financial Offices) and 2. taxpayers in the period ranging from January 1, 2013 to December 31, 2017. Successful Cases means that the SAC decided in accordance with provisions of the Act on the Code of Administrative Justice ${ }^{34}$ to set aside a Regional Court's decision and eventually returned the case to that Court on the basis of a cassation complaint filed either by the 1. Financial Office or 2. the taxpayer. On the other hand, Failed Cases I shall have the meaning of a Regional Court's ruling confirmed by the SAC and a rejection of the cassation complaint filed either by 1 . the Financial Office or 2. the taxpayer. Failed Cases II means that in accordance with provisions of the Act on the Code of Administrative Justice, the SAC decided to set aside a Regional Court's ruling and to reject the taxpayer's legal action when ruling on the basis of a cassation complaint filed by the taxpayer.

The Financial Administration filed only 6 cassation complaints in total, 3 of them were successful (i.e. the SAC annulled a Regional Court's ruling and returned the case to it) and 3 of them were unsuccessful (i.e. the SAC confirmed a Regional Court's ruling). On the other hand, taxpayers filed 103 cassation complaints in total, whereby 30 were successful (i.e. the SAC annulled a Regional Court's ruling and returned the case to it) and 73 unsuccessful (i.e. the SAC confirmed a Regional Court's ruling or annulled it and rejected the legal action as inadmissible).

Table 3.

Success and failure of appellants in 2013-2017

\begin{tabular}{|l|l|r|r|r|r|r|c|}
\hline & \multicolumn{1}{|c|}{ Year } & 2013 & 2014 & 2015 & 2016 & 2017 & $\begin{array}{c}\text { 2013-2017 total } \\
\text { success/failure }\end{array}$ \\
\hline $\begin{array}{l}\text { Financial Office } \\
\text { submitted a Cassation } \\
\text { Complaint }\end{array}$ & Successful Cases & 0 & 1 & 1 & 0 & 1 & 3 \\
\cline { 2 - 8 } & Failed Cases I & 0 & 1 & 1 & 0 & 1 & 3 \\
\hline \multirow{2}{*}{$\begin{array}{l}\text { Taxpayer submitted } \\
\text { a Cassation } \\
\text { Complaint }\end{array}$} & Successful Cases & 3 & 4 & 8 & 3 & 12 & 30 \\
\cline { 2 - 8 } & Failed Cases I & 3 & 17 & 11 & 20 & 17 & 68 \\
\cline { 2 - 8 } & Failed Cases II & 1 & 0 & 1 & 3 & 0 & 5 \\
\hline
\end{tabular}

Source: Compiled by the authors. 
Table 4 shows the total number of successful and unsuccessful cases of both 1 . the Financial Administration (its Financial Offices) and 2. taxpayers in the period ranging from January 1, 2013 to December 31, 2017. The Financial Administration's successful cassation complaints (Successful Cases) are aggregated with the failed cassation complaints brought by taxpayers (Failed Cases I and II). It results the total number of 76 successful cases of the Financial Administration. On the other hand, if the same calculation is applied to taxpayers, all of the Financial Administration's failed cassation complaints (Failed Cases I) have to be aggregated with the taxpayers' successful cassation complaints (Successful Cases). Here, some 33 taxpayers' and 76 Financial Administration's total successful cases result.

Table 4.

Total successful cases in 2013-2017

\begin{tabular}{|c|c|c|c|c|c|c|}
\hline Year & 2013 & 2014 & 2015 & 2016 & 2017 & $2013-2017$ in total \\
\hline $\begin{array}{l}\text { Financial Office's } \\
\text { Successful Cases }\end{array}$ & 0 & 1 & 1 & 0 & 1 & 3 \\
\hline $\begin{array}{l}\text { Taxpayers' Failed Cases I } \\
\text { and II }\end{array}$ & $3+1$ & $17+0$ & $11+1$ & $20+3$ & $17+0$ & 73 \\
\hline $\begin{array}{l}\text { Financial Office's Total } \\
\text { Successful Cases }\end{array}$ & 4 & 18 & 13 & 23 & 18 & 76 \\
\hline Year & 2013 & 2014 & 2015 & 2016 & 2017 & $2013-2017$ in total \\
\hline $\begin{array}{l}\text { Financial Office's Failed } \\
\text { Cases I }\end{array}$ & 0 & 1 & 1 & 0 & 1 & 3 \\
\hline $\begin{array}{l}\text { Taxpayer's Successful } \\
\text { Cases }\end{array}$ & 3 & 4 & 8 & 3 & 12 & 30 \\
\hline $\begin{array}{l}\text { Taxpayer's Total } \\
\text { Successful Cases }\end{array}$ & 3 & 5 & 9 & 3 & 13 & 33 \\
\hline
\end{tabular}

Source: Compiled by the authors.

Table 5 depicts the average success rates of the Financial Administration before the SAC in the period 2013-2017. The figures for the Financial Offices' Total Successful Cases are taken from Table 4 and further divided by the figures of the Total No. of Cases extracted from Table 1, which is afterwards multiplied by one hundred (converted to percentage ratio) and rounded down to the nearest unit. From this calculation result the percentage ratios (rounded Average Success Rate) for each year and the total percentage ratio (rounded Total Average Success Rate) in the right bottom field for the whole five-year period. 
Table 5.

Average Success Rates of the Financial Administration in 2013-2017

\begin{tabular}{|l|c|c|c|c|c|c|}
\hline \multicolumn{1}{|c|}{ Year } & 2013 & 2014 & 2015 & 2016 & 2017 & $2013-2017$ in total \\
\hline Total Cases & 7 & 23 & 22 & 26 & 31 & 109 \\
\hline Total Successful Cases & 4 & 18 & 13 & 23 & 18 & 76 \\
\hline $\begin{array}{l}\text { Average Success Rate } \\
\text { (rounded) }\end{array}$ & $57 \%$ & $78 \%$ & $59 \%$ & $88 \%$ & $58 \%$ & $68 \%$ \\
\hline
\end{tabular}

Source: Compiled by the authors.

Finally, on the basis of the above calculations, it can be concluded that in the period 20132017, the Financial Administration had an average success rate of $68 \%$ in the SAC's rulings on cassation complaints challenging the decisions of Regional Courts on legal actions of taxpayers against unlawful interference by the Financial Offices. From this, it can be further concluded, that if 1 . decided on the merits of the case by the Regional Court and 2. later subject to a cassation complaint (filed either by a Financial Office or taxpayer), there were on average some $32 \%$ successful legal actions of taxpayers against unlawful interference by a Financial Office with the taxpayers' rights.

In our view, on the basis of these data it is not yet possible to recognise a clear curve of increase or decrease in cases related to unlawful interference in tax matters decided by the SAC, neither a clear curve of success or failure of the Financial Administration since the figures vary significantly year by year in the five-year period: 57\% (2013), 78\% (2014), $59 \%$ (2015), 88\% (2016) and 58\% (2017). A further research reflecting other types of legal actions has to be conducted in order to obtain more data and draw general conclusions.

\section{Conclusion}

In the Czech Republic, in principle any administrative decision, interference or failure to act of an administrative authority can be challenged before the administrative justice by way of a legal action brought by natural and legal persons. The actions and measures of tax authorities are no exception as the tax authorities are only considered specialised administrative authorities. One of the currently discussed problems of Czech tax law and tax administration is the recently adopted restrictive approach of the tax authorities towards taxpayers. The media have reported an increasing number of cases in which actions and measures of the tax authorities have been found unlawful by the administrative courts.

While only a taxpayer can sue the tax authority before the Regional Court by bringing one of the three legal actions coming into consideration, i.e. 1. a legal action against a decision of a tax authority; 2. a legal action for the failure of a tax authority to act and 3. a legal action against unlawful interference by a tax authority; extraordinary remedy against a Regional Court's ruling in the form of a cassation complaint can be brought before the SAC both by the tax authority and the taxpayer. 
The quantitative research conducted by the authors aims to analyse cassation complaints in all of the three fields, i.e. cassation complaints seeking to set aside rulings of the Regional Courts that decided on 1. legal actions against a decision of a Financial Office; 2. legal actions for the failure of a Financial Office to act; and 3. legal actions against unlawful interference by a Financial Office with the taxpayers' rights. It is thus based on determining the success rate of the Financial Administration in the proceedings on cassation complaints before the SAC.

According to our calculations the quantitative research consists in an analysis of several thousand rulings of the SAC. We have thus resulted to proceed step by step and first analysed the SAC's rulings on cassation complaints against the Regional Courts' decisions on legal actions against unlawful interference by a Financial Office as the tax authority. In the paper there have been presented results of the first part of the quantitative research.

In view of the new structure of the Financial Administration of the Czech Republic as of January 1, 2013, we have decided to cover the period of the last five years (from January 1, 2013 to December 31, 2017). It can be concluded that in the period 2013-2017, the Financial Administration had a total average success rate of $68 \%$ in the SAC's rulings on cassation complaints challenging the rulings of Regional Courts on legal actions of taxpayers against unlawful interference by the Financial Administration. The figures of average success rates differ significantly year by year: 57\% (2013), 78\% (2014), 59\% (2015), $88 \%(2016)$ and $58 \%(2017)$.

The obtained data are part of a much broader quantitative research to be realised in the near future. The follow-up research will include an analysis of several thousand rulings. We hope the chosen methodology and approach might serve as an inspiration for other legal scholars and practitioners in other jurisdictions considering to undertake a similar approach towards a better understanding of public administration and especially administration of taxes by tax authorities. 


\section{References}

1 Eurostat, Flash estimate for the first quarter of 2018, May 15, 2018, http://ec.europa.eu/eurostat/documents /2995521/8897618/2-15052018-BP-EN.pdf/defecccc-f9d9-4636-b7f8-d401357aca46 (accessed 21 June 2018).

2 Eurostat, Unemployment statistics, April 2018, http://ec.europa.eu/eurostat/statistics-explained/index.php/ Unemployment_statistics\#Recent_developments_in_unemployment_at_a_European_and_Member_State_ level (accessed 21 June 2018).

3 The Czech Statistical Office, Wages and Labour, June 4, 2018, www.czso.cz/csu/czso/labour_and_earnings_ ekon (accessed 21 June 2018).

4 Ian Willoughby, Record Exports Recorded for 2017 but Imports Grew Faster, February 5, 2018, www.radio. $\mathrm{cz} / \mathrm{en} /$ section/business/record-exports-recorded-for-2017-but-imports-grew-faster (accessed 21 June 2018).

5 The Czech National Bank, Inflation Report - II/2018, www.cnb.cz/en/monetary-policy/inflation-reports/ Inflation-Report-II-2018/ (accessed 21 June 2018).

6 The Czech National Bank, Financial Stability Report 2017/2018, www.cnb.cz/export/sites/cnb/en/financialstability/.galleries/fs_reports/fsr_2017-2018/fsr_2017-2018.pdf (accessed 21 June 2018).

7 Komercni Banka, Czech Economic Outlook 2018: Richer households, stronger koruna, January 30, 2018. www. kb.cz/getmedia/99bc4abd-bacd-4637-811e-0d3441f76a60/kb-economic-outlook-q1-2018.pdf.aspx (accessed 21 June 2018).

8 Deloitte, Czech Economic Outlook for 2018, December 2018, www2.deloitte.com/content/dam/Deloitte/ cz/Documents/deloitte-analytics/Czech-Economic-Outlook-for-2018.pdf (accessed 21 June 2018); KPMG. Czech economy in 2018: Stable growth with signs of overheating, 4 January 2018, www2.deloitte.com/cz/en/ pages/press/articles/cze-tz-ceska-ekonomika-v-roce-2018-stabilni-rust-se-znamkami-prehrivani.html (accessed 21 June 2018).

9 European Commission, Economic forecast for Czechia, 2018, https://ec.europa.eu/info/business-economyeuro/economic-performance-and-forecasts/economic-performance-country/czech-republic/economicforecast-czech-republic_cs (accessed 21 June 2018).

10 Organisation for Economic Co-operation and Development, The Czech Republic - Economic forecast summary (May 2018), www.oecd.org/eco/outlook/czech-republic-economic-forecast-summary.htm (accessed 21 June 2018).

11 Ministry of Finance of the Czech Republic, Macroeconomic Forecast - April 2018, www.mfcr.cz/en/statistics/ macroeconomic-forecast/2018/macroeconomic-forecast-april-2018-31529 (accessed 21 June 2018).

12 Czech National Bank, CNB current forecast (Announced on 3 May 2018), www.cnb.cz/en/monetary-policy/ forecast/cnb-forecast-archive/CNB-forecast-May-2018/ (accessed 21 June 2018).

13 The optimistic expectations of entrepreneurs are confirmed by the data of the Czech Statistical Office according to which at the end of 2017, the overall confidence of entrepreneurs in the economy was even the highest since 2008. Czech Statistical Office, Czech Republic: Business cycle survey - December 2017, www. czso.cz/csu/czso/ari/business-cycle-survey-december-2017 (accessed 21 June 2018).

14 According to a survey conducted by KMPG, managers of major corporations operating in the Czech Republic consider frequent legislative modifications to be the most significant issue. KPMG, Survey: Czech tax environment not supportive of business, 2017, http://danovky.cz/en/survey-czech-tax-environment-notsupportive-of-business (accessed 21 June 2018); KPMG, Čeští top manažeři volají po jednoduššich danich a podpoŕe inovaci [Czech top managers call for simpler taxes and innovation support] 2017, https://home. kpmg.com/cz/cs/home/pro-media/tiskove-zpravy/2017/11/pruzkum-manazeri-dane-inovace.html (accessed 21 June 2018). 
15 For example, the deputy chairman of the Supreme Court of the Czech Republic Roman Fiala considers the Czech legal system so complicated and unclear that it is slowly ceasing to work. Josef Pravec, Právo je v jedné zemi jen jedno. Pokud by to neplatilo, tak západni demokracie v Evropě končí, ríká mistopréedseda Nejvyšš́ho soudu ČR Roman Fiala [There is only a single law in a country. If now, Western democracy in Europe ends, says Vice-President of the Supreme Court of the Czech Republic Roman Fiala] 2017, http://m.ihned.cz/ ekonom/c1-65642720-pravo-je-v-jedne-zemi-jen-jedno-pokud-by-to-neplatilo-tak-zapadni-demokracie-vevrope-konci-rika-mistopredseda-nejvyssiho-soudu-cr-roman-fiala (accessed 21 June 2018).

16 In the $7^{\text {th }}$ Parliamentary Term (2013-2017) of the Chamber of Deputies (the Upper House of the Czech Parliament), 357 laws were adopted. This is an average of 90 legal acts (statutes) with the legal force of law each year, i.e. almost two laws passed every week in the past four years. See the search results on the website of the Chamber of Deputies of the Parliament of the Czech Republic after setting up a general overview of the parliamentary prints - draft laws (bills) that were approved in the $7^{\text {th }}$ parliamentary term and published in the Collection of Laws: Chamber of Deputies of the Parliament of the Czech Republic, in Parliamentary Publications, $7^{\text {th }}$ Parliamentary Term (2013-2017) 2018, www.psp.cz/sqw/sntisk.sqw (accessed 21 June 2018).

17 Jirina Prochazkova, Aktuálni praxe finančni správy [Current Practice of Financial Administration] July 25, 2018, https://archiv.ihned.cz/c1-66177260-aktualni-praxe-financni-spravy (accessed 21 June 2018).

18 Tana Kralova, Alzbeta Vejvodova, $Z$ podnikateli se stali podezřeli. Zde je deset rad Ekonomu, jak se bránit dañové šikanè [Entrepreneurs have become suspects. Here are the ten tips, how to resist tax bullying] July 12, 2017, https://ekonom.ihned.cz/c1-65797810-z-podnikatelu-se-stali-podezreli-zde-je-deset-rad-ekonomujak-se-branit-danove-sikane (accessed 21 June 2018).

19 Victor Dusek, Veronika Cervenkova, Increasingly restrictive measures to secure tax collection, May 15, 2017, http://danovky.cz/en/increasingly-restrictive-measures-to-secure-tax-collection (accessed 21 June 2018).

20 Jan Prokes, Se zajištovacimi príkazy šetretete, žádaji poslanci finančni správu. Vysvètlovat byl i ministr Pilný [MPs request ask the financial adminstration: keep calm with the securing orders. Minister Pilny was also explaining] September 19, 2017, https://zpravy.aktualne.cz/ekonomika/se-zajistovacimi-prikazy-setrete-zadaji-poslancifinancni-sp/r 2e5c7a1c9d4e11e7b128002590604f2e/ (accessed 21 June 2018).

21 Veronika Cervenkova, Martina Valachova, Tax administrators obliged to continuously review conditions for securing tax, August 17, 2017, http://danovky.cz/en/tax-administrators-obliged-to-continuously-reviewconditions-for-securing-tax (accessed 21 June 2018).

22 Tana Kralova, Nejvy̌šsi správni soud dál kroti finančni správu v jeji horlivosti při výbèru DPH [The Supreme Administrative Court continues to correct the financial administration in its efforts to collect VAT] March 17, 2018, https://pravniradce.ihned.cz/c1-66068470-nejvyssi-spravni-soud-dal-kroti-financni-spravu-v-jejihorlivosti-pri-vyberu-dph (accessed 21 June 2018); Ceska tiskova kancelar. Soud se v daňovém sporu zastal firmy v údajném podvodném retézci [The court upheld a company in a tax dispute over the alleged fraudulent chain] February 13, 2018, www.pravniprostor.cz/aktuality/aktuality/soud-se-v-danovem-sporu-zastal-firmyv-udajnem-podvodnem-retezci (accessed 21 June 2018); Ceska tiskova kancelar. FAU vyhrála spor s Finančni správou, rozsudek poturdil NSS [FAU won a dispute with the Financial Administration, the decision confirmed by the SAC] December 1, 2017, www.pravniprostor.cz/aktuality/aktuality/fau-vyhrala-spor-s-financnispravou-rozsudek-potvrdil-nss (accessed 21 June 2018); Lenka Zlamalova, Soudci zastavují nezákonné rádèní Babišovy ministryně [The judges stop the unlawful conduct of Babis's minister] April 4, 2018, https://echo24. $\mathrm{cz} / \mathrm{a} / \mathrm{S} 9 \mathrm{BxR} /$ soudci-zastavuji-nezakonne-radeni-babisovy-ministryne?utm_source=www.seznam.cz\&utm_ medium=sekce-z-internetu (accessed 21 June 2018).

23 Tomas Hajdusek, 3 príklady, kdy finanční úrady ignorovaly rozsudky Nejvyššího správního soudu [3 examples where the tax authorities ignored the judgments of the Supreme Administrative Court] February 6, 2018, www.podnikatel.cz/clanky/mely-by-financni-urady-respektovat-rozhodnuti-spravnich-soudu/ (accessed 21 June 2018). 
24 Financial Administration of the Czech Republic, Martin Janeček, Finanční správa nikoho nelikviduje, žádné zadávání úkoli nefunguje [The Financial Administration eliminates no one, no task assignment is in place] September 13, 2017, www.financnisprava.cz/cs/financni-sprava/pro-media/FS-v-mediich/2017/martinjanecek-financni-sprava-nikoho-ne-8749 (accessed 21 June 2018); Ministry of Finance of the Czech Republic, Zástupci Ministerstva financi se zúcastnili odborného semináre k zajištovacím príkazưm [Representatives of the Ministry of Finance participated in a seminar on securing orders] October 30, 2017, www.mfcr.cz/cs/ aktualne/tiskove-zpravy/2017/zastupci-ministerstva-financi-se-zucastn-29999 (accessed 21 June 2018).

25 Financial Administration of the Czech Republic, Nejvyšsí správni soud zamitl kasačni stižnost firmy KM Plus ve sporu o zajištovaci príkazy proti Finančni správé [The Supreme Administrative Court rejected KM Plus's cassation complaint in a dispute over securing orders with the Financial Administration] December 18, 2017, www.financnisprava.cz/cs/financni-sprava/pro-media/tiskove-zpravy/2017/nejvyssi-spravni-soud-zamitlkasacni-sti-8934 (accessed 21 June 2018).

26 Financial Administration of the Czech Republic, Rozsudek NSS nic prevratného neprínesl [The SAC's judgment has not brought anything new] February 15, 2018, www.financnisprava.cz/cs/financni-sprava/pro-media/ nepresnosti-v-mediich/2018/Rozsudek-k-NSS-nic-prevratneho-neprinesl-9071 (accessed 21 June 2018).

27 Based on the Act No. 456/2011 Coll., on the Financial Administration of the Czech Republic, as amended.

28 Financial Administration of the Czech Republic, General Financial Directorate, www.financnisprava.cz/en/ financial-administration/general-financial-directorate (accessed 21 June 2018).

29 Article 4 of Act No. 150/2002 Coll., the Code of Administrative Justice, as amended.

30 Supreme Administrative Court, Remedies against decisions of administrative courts, January 6, 2014, www. nssoud.cz/Remedies-against-decisions-of-administrative-courts/art/496?menu=316 (accessed 21 June 2018).

31 Supreme Administrative Court, Protection against unlawful interference, December 18, 2014, www.nssoud. cz/-p-Protection-against-unlawful-interference-p-/art/491?menu=311 (accessed 21 June 2018).

32 Supreme Administrative Court, Protection against unlawful interference, December 18, 2014, www.nssoud. $\mathrm{cz} /$-p-Protection-against-unlawful-interference-p-/art/491?menu=311 (accessed 21 June 2018).

33 Supreme Administrative Court, Rozhodovaci ćinnost. Rozhodnutí správnich soudü. Plný formulàr [Decisionmaking. Decisions of administrative courts. Full form.] www.nssoud.cz/main0Col.aspx?cls=JudikaturaExtended Search\&pageSource $=0$ (accessed 21 June 2018).

34 Article 4 of Act No. 150/2002 Coll., the Code of Administrative Justice, as amended. 